\title{
AC IMPEDANCE SPECTROSCOPY OF Al/a-SiC/c-Si(p)/Al HETEROSTRUCTURE UNDER ILLUMINATION
}

\author{
Milan Perný ${ }^{*}$ - Vladimír Šály ${ }^{*}$ - Michal Váry ${ }^{*}$ \\ Miroslav Mikolášek ${ }^{*}$ - Jozef Huran ${ }^{* *}$ — Juraj Packa ${ }^{*}$
}

\begin{abstract}
The amorphous silicon carbide/crystalline silicon heterojunction was prepared and analyzed. The current-voltage $(I-$ $V)$ measurements showed the barrier properties of prepared sample. Biased impedance spectra of $\mathrm{Al} / \mathrm{a}-\mathrm{SiC} / \mathrm{c}-\mathrm{Si}(\mathrm{p}) / \mathrm{Al}$ heterojunction under the standard illumination are reported and analyzed. AC measurements in the illuminated conditions were processed in order to identify electronic behavior using equivalent AC circuit which was suggested and obtained by fitting the measured impedance data. A phenomenon of negative capacitance/resistance in certain frequency range has been observed.
\end{abstract}

K e y w or d s: PECVD, heterojunction, silicon carbide, equivalent AC circuit, complex impedance

\section{INTRODUCTION}

Slightly doped amorphous silicon carbide layers a-SiC (alternatively modified with other chemical elements, eg nitrogen $\mathrm{N}$ in our case) which form heterojunction with crystalline silicon are relevant substitute for amorphous silicon (a-Si:H). The conversion efficiency up to $22 \%$ of heterojunction solar cell (a-Si:H/c-Si) was reported and any further substantially increase is not expected [1]. In the case of amorphous silicon the problem lies in increased recombination when a thicker layer of a-Si:H is used. Short circuit current $I_{s c}$ of a-Si:H/c-Si solar cell structures is expected to increase when a-Si:H is substituted by a larger band gap material.

The width of the band gap can be controlled in a wide range in the case when carbon is added to the amorphous a-Si:H (resulting in hydrogenated silicon carbide alloy at greater amount of carbon). Increased carbon concentration $(x)$ in $a-\mathrm{Si}_{x} \mathrm{C}_{1-x}: \mathrm{H}_{y}$ leads to better light absorption efficiency of heterojunction a-SiC:H/c-Si solar cells [2]. Deterioration of electronic properties (mainly electron mobility decrease) due to various kinds of amorphous network structural disorder is a negative accompanying phenomenon related to increasing concentration of carbon. In limit case, when the carbon concentration is closed to $100 \%$, it leads to creation of amorphous carbon layers or diamond-like carbon films, respectively. Thin films of amorphous $\mathrm{SiC}$ or amorphous $\mathrm{C}$ as an emitter layer for heterojunction solar cells applications has been the subject of several studies $[3,4]$ but commercial outputs in the form of heterojunction solar cell devices still lack. Optimization of technology (deposition parameters, precursor gases, doping) has been the subject of research [5-8] and is still a major challenge for further research.
Other applications, in addition to the use of a-SiC as an emitter layer of mentioned heterostructures, are possible and have been investigated. Thin a-SiC can be used as diffusion barrier, passivation layer and a barrier layer, eg within the structure of amorphous silicon solar cells. This alloys shows to be promising also as both, etch stop $[9,10]$ and hard mask layer [11] to assist nanoelectronic patterning, and as low dielectric constant (known as low-k) interfacial dielectric material [12], diffusion barrier [13-15], and pore sealants [16]. Controllability of the band gap allows a wide range of applications especially in microelectronics, including thin dielectric layers and semiconductor applications. Optoelectronic applications as another important area include the use of a-SiC photodiodes in optical communications [17], optical/image sensors [18] and LED's applications [19]. Another field of applications a-SiC has found in micro electromechanical systems [20].

The DC and AC measurements under illumination were performed in order to detect the electronic properties and PV parameters of chosen prepared sample which was prepared in the context of previous research of optimization the technology [21].

\section{EXPERIMENTAL}

The plasma CVD reactor with parallel plate electrodes was used for samples preparation. A p-type silicon wafer with resistivity $6-10 \Omega \mathrm{cm}$ and (100) orientation was used as the substrate for the growth of SiC layers doped by nitrogen $(\mathrm{SiC}(\mathrm{N}))$. Technological conditions for sample preparation were: gas mixture $\left(\mathrm{SiH}_{4}-5 \mathrm{sccm}\right.$, $\mathrm{CH}_{4}-30 \mathrm{sccm}, \mathrm{NH}_{3}-3 \mathrm{sccm}, \mathrm{H}_{2}-100 \mathrm{sccm}$, Ar-10 sccm). The temperature of substrate during the deposition was

\footnotetext{
* Slovak University of Technology, Faculty of Electrical Engineering and Information Technology, Ilkovičova 3, SK-81219 Bratislava, Slovakia, milan.perny@stuba.sk, ${ }^{* *}$ Slovak Academy of Sciences, Institute of Electrical Engineering, Dúbravská cesta 9, 84104 Bratislava, Slovakia
} 


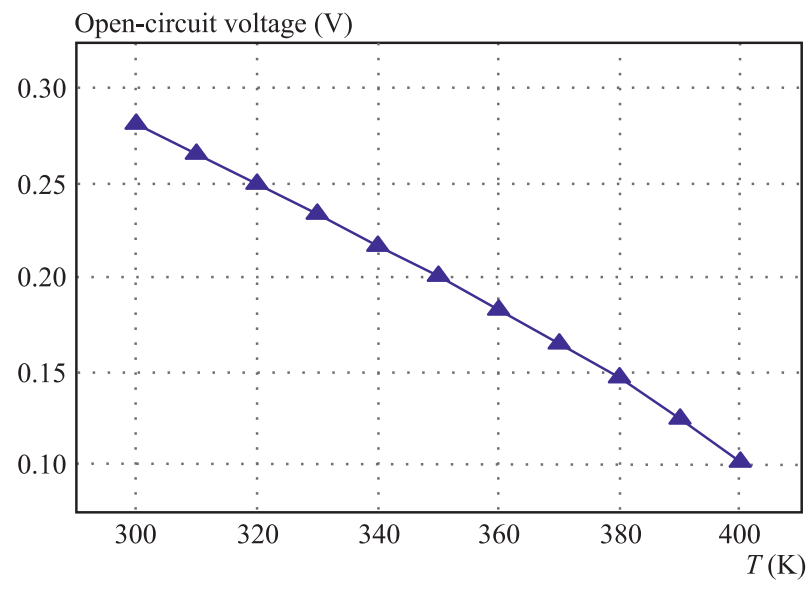

Fig. 1. Open circuit voltage temperature dependences at irradiation intensity $945 \mathrm{Wm}^{-2}$ of prepared sample

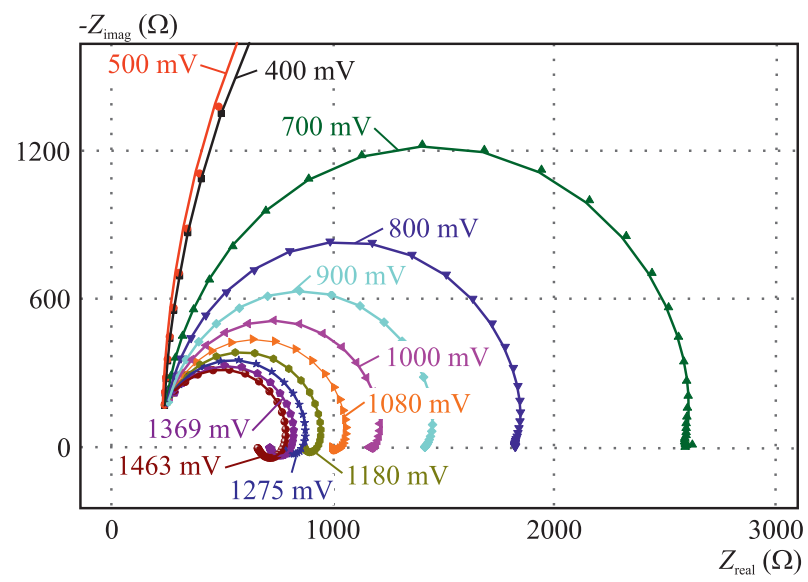

Fig. 2. Measured (symbol) and fitted (line) impedance spectra of $\mathrm{Al} / \mathrm{a}-\mathrm{SiC} / \mathrm{c}-\mathrm{Si}(\mathrm{p}) / \mathrm{Al}$ sample under illumination at room temperature at different forward bias

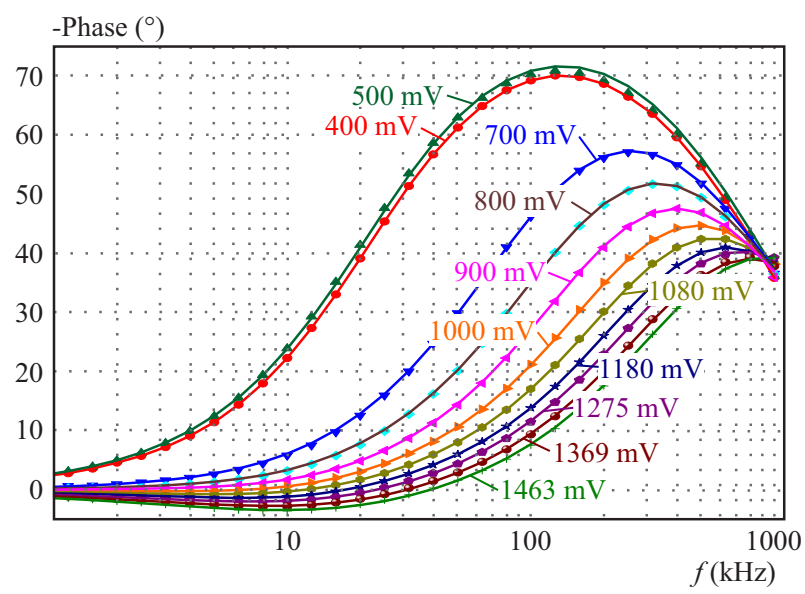

Fig. 3. Measured (symbol) and fitted (line) frequency dependence of impedance phase at room temperature in the dark of sample T3

$300{ }^{\circ} \mathrm{C}, \mathrm{RF}$ power $100 \mathrm{~W}$ and pressure $35 \mathrm{~Pa}$ in the chamber. Introduction of the hydrogen to the gas mixture results in the production of samples which can be denoted as a-SiC(N):H films (for simplification further denoted here only as an a-SiC). The circular electrodes of $\mathrm{Al}$
(120 nm thick) were formed on the side with $\mathrm{SiC}$ film on each sample. The ohmic contact on the opposite side of samples was created - the whole area Al, app. $250 \mathrm{~nm}$ thick. Other technological parameters can be found in [21]. The samples formed on $\mathrm{Si}$ were annealed in a furnace with forming gas atmosphere $(90 \% \mathrm{~N}, 10 \% \mathrm{H})$ for $30 \mathrm{~min}$ (heated $100^{\circ} \mathrm{C} / \mathrm{min}$ from room temperature) at temperature $430{ }^{\circ} \mathrm{C}$ and pressure $1 \mathrm{kPa}$.

DC measurements were performed using Keithley 237 at the temperatures within the interval from $300 \mathrm{~K}$ to $400 \mathrm{~K}$ and controlled by program DCATS. AC impedance spectroscopy measurement and characterization was performed by SOLARTRON Analytical Module. The measurements were done under illumination within the frequency range from $1 \mathrm{~Hz}$ to $1 \mathrm{MHz}$. Solar simulator ORIEL class AAA was used for the measurement of PV parameters of illuminated sample.

\section{RESULTS AND DISCUSSION}

The results obtained from dark I-V measurements (presented in [21]) indicate the barrier properties of prepared structure and presence of photovoltaic effect was observed under illumination. Basic PV parameters ( $V_{o c}$ and $F F$ ) were determined as $V_{o c}=0.292, F F=0.20$. The efficiencies were not calculated while with regard to character of prepared samples (top point contacts) we cannot exactly define the geometry and obtain exact "solar cell" area of the structure. The shape of $I-V$ curves is strongly influenced by series resistance. High series resistance results in low FF. Temperature dependence of open-circuit voltage were also measured under illumination and the results are shown in Fig. 1. The dependence of open-circuit voltage on the temperature shows linear behavior. Finally that means that the conversion efficiency decreases when the temperature increases as it is generally common.

AC impedance spectroscopy characterization was performed by SOLARTRON Analytical Module in order to detect the frequency response of $\mathrm{Al}-\mathrm{a}-\mathrm{SiC} / \mathrm{c}-\mathrm{Si}(\mathrm{p}) / \mathrm{Al}$ heterojunctions and identify equivalent circuit of $\mathrm{Al}-\mathrm{a}-\mathrm{SiC} / \mathrm{c}-\mathrm{Si}(\mathrm{p}) / \mathrm{Al}$ samples. The measurements were performed at room temperature and on illuminated samples in the frequency range from $1 \mathrm{~Hz}$ to $1 \mathrm{MHz}$ and also at different forward bias voltages. Measured impedance spectra or Nyquist characteristics are shown in Fig. 2. At frequencies up to $50 \mathrm{kHz}$ and DC biases higher than $1000 \mathrm{mV}$ the frequency response of complex impedance related to standard models of capacitive samples is not more valid. The positive values of Zimag were obtained at low frequencies, usually ascribed to inductive character of the impedance.

For more detailed analyses we introduce the dependence of phase angle on frequency shown in Fig. 3. Given the nature of the studied impedance (thin a-SiC layer between two electrodes) the capacitance character of samples and negative phase on the whole frequency range 


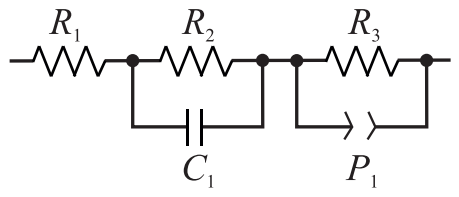

Fig. 4. Proposed equivalent circuit of the heterostructure $\mathrm{Al}-\mathrm{a}-\mathrm{SiC} / \mathrm{c}-\mathrm{Si}(\mathrm{p}) / \mathrm{Al}$

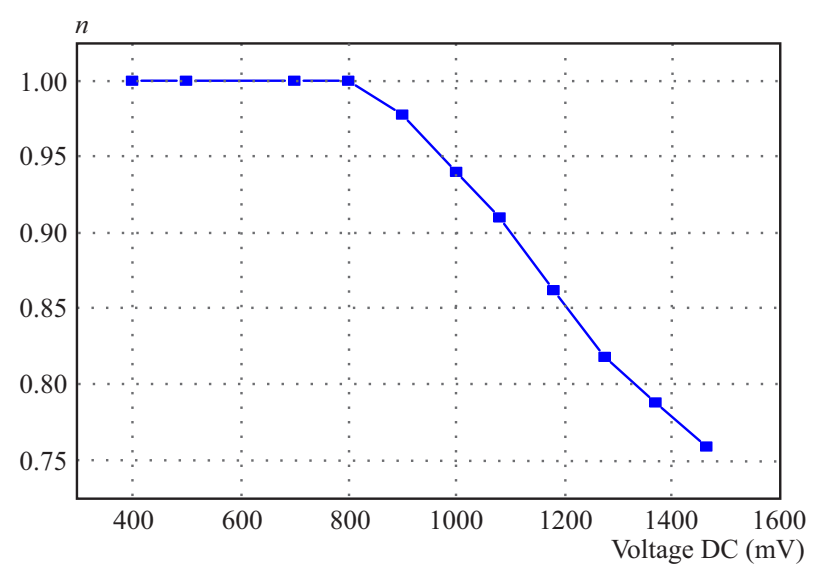

Fig. 5. Power law factor $n$ as a function of applied DC bias

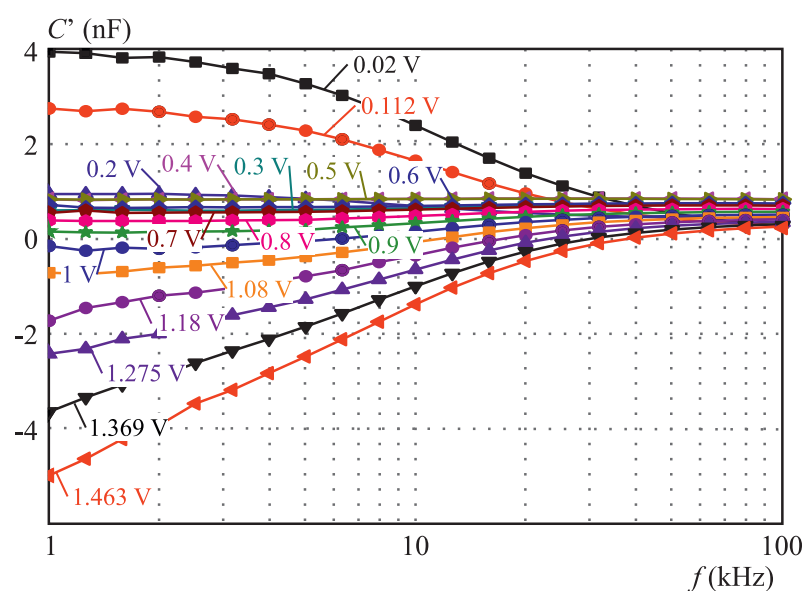

Fig. 6. Real part of AC Capacitance $(C)$ as a function of forward bias voltage at room temperature under illumination

would be expected. As shown in Fig. 3, the positive phase of the complex impedance can be observed. It is at higher bias voltages, app. $1000 \mathrm{mV}$, and at frequencies lower than approximately mentioned $50 \mathrm{kHz}$. Usually such frequency dependence is attributed to the conventional inductance of the system (generally ascribed to the electric conductive interconections). In our case such reasoning would be incorrect for two main reasons. The inductance makes sense when strong magnetic field is applied, which is not the case here. And also, for the case that classical inductance $I Z I=\omega L$ and its influence could be observed, however, it is so at higher frequencies, often about $1 \mathrm{MHz}$. Therefore, the anomalous behavior in Fig. 3 is not the result of parasitic inductance. Similar explanation can be found in [18].

It is evident that the simple equivalent circuit with one parallel $R C$ combination must be modified and the contribution of the interfacial states has to be taken into account. They offer an additional conductive path related to the recombination in the junction. According to the theory presented in [23] each energy level $E_{i}$ in the band gap introduces one $C R$ time constant. We have searched for the best fitting circuit with regard to the shape of frequency dependence of impedance spectra (Fig. 2) and their phase (Fig. 3). Usually the transport processes related to the junction of heterostructures are represented as connection of $R$ and $C$ elements. In our case we introduce constant phase element $P$ except of capacitor. The measured network reflects the contribution of the junction $C_{1}$ parallel to $G_{2}=1 / R_{2}$, the interface states $P_{1}$ parallel to $G_{3}=1 / R_{3}$ and series resistance $R_{1}$. We have decided to use series connection of parallel $R C$ elements while in the case when resistor R3 is of small values, as it is in the case of lower voltages and shown in Fig. 4, constant phase element $P_{1}$ is actually shunted by parallel resistor $R_{3}$.

Constant phase element ( $\mathrm{CPE}$ ) in $\mathrm{AC}$ equivalent circuit represents different inhomogenities such as blocking effects (interfacial states, porosities, etc). The electrical impedance of $\mathrm{CPE}$ is expressed as

$$
Z_{C P E}=1 / C_{P E}(i \omega)^{n} .
$$

$\mathrm{CPE}$ is in fact classical capacitors in the case when $n=1$. Variation of exponent $n$ on the applied DC voltage is shown in Fig. 5. As can be seen in Fig. 5, CPE behaves like a classical capacitor only when low levels of DC bias are applied.

The measured real part of capacitance at low bias voltages $(\mathrm{V})$ is positive and decreases with increasing bias as can be seen in Fig. 6 .

For higher forward bias voltages $(\mathrm{V})$, the real part of capacitance turns to negative values. This effect was also observed and presented either on organic [24] or inorganic layered structures [25]. The phenomenon can be attributed to the carrier capture and emission from the interface states. The negative capacitance can be attributed to the existence of defect states at the interfaces between crystalline semiconductor and amorphous carbide layer [26].

The parallel resistances $R_{2}$ and $R_{3}$ of equivalent $\mathrm{AC}$ circuit were estimated under illumination at different bias conditions. The resistances $R_{2}$ and $R_{3}$ are dependent on the applied voltage. Decrease of the resistance in the case of $R_{2}$ and $R_{3}$ with increasing forward bias is depicted in Fig. 7. Negative resistance was detected in the case of $R_{3}$ at higher biases what is consistent with the ideas mentioned above. Series resistance $R_{1}$ is quite high and only a little influenced by voltage bias.

\section{CONLCUSIONS}

The heterojunction structure $\mathrm{Al} / \mathrm{a}-\mathrm{SiC} / \mathrm{c}-\mathrm{Si}(\mathrm{p}) / \mathrm{Al}$ prepared by PECVD method was studied by electrical analyses. The prepared samples show photovoltaic behavior 


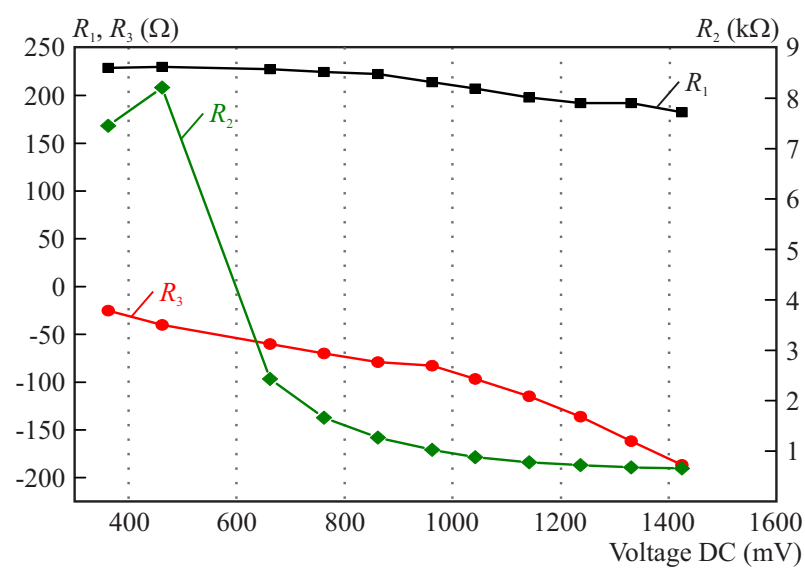

Fig. 7. Equivalent circuit resistances as a function of applied bias under illumination at room temperature (the connecting lines are not a functional equivalent)

and basic PV parameters were determined from currentvoltage $(\mathrm{I}-\mathrm{V})$ characteristics under light. The impedance spectroscopy (the measurements under illumination) was applied to study the electric properties and equivalent AC circuit was estimated. Anomalous behaviour of the complex impedance character at lower frequencies and higher forward bias voltages was detected and discussed. The negative capacitance indicates the existence of defect states at the interface between crystalline semiconductor and amorphous layer. The impedance spectroscopy shows to be convenient powerful method to reveal such interesting behaviour and improve the picture about the transport processes in studied structures.

\section{Acknowledgement}

This work was supported by the Slovak Research and Development Agency (APVV) under the Contract No APVV-0443-12.

\section{REFERENCES}

[1] KANNO, H.-IDE, D.-TSUNOMURA, Y.-TAIRA, S.-BABA, T.-YOSHIMINE, Y.-TAGUCHI, M.-KINOSHITA, T.-SAKATA, H.-MARUYAMA, E.: Over $22 \%$ Efficient HIT Solar Cell, In: Proceedings of the 23rd European photovoltaic solar energy conference and exhibition, Valencia, Spain, 2008, pp. 1136-1139.

[2] STREET, R. A.: Technology and Applications of Amorphous Silicon, Springer, New York, 2000.

[3] CHANG, Y. L.-CHEN, M. Y.-LIU, J. S. Q.-CHIEN, Y. J.-YANG, P. C.-HUANG, M. Y.: Silicon Carbide Emitter for Heterojunction Solar Cells (2013), 1210-1212.

[4] LEE, C. H.-LIM, K. S.: Boron-Doped Amorphous Diamondlike Carbon as a New p-Type Window Material in Amorphous Silicon p-i-n Solar Cells, Appl. Phys. Lett. 72 (1998), 106.

[5] HAMAKAWA, Y.: Present Status of Solar Photovoltaic R\&D Projects in Japan, Surf. Sci. 86 (1979), 444-461.

[6] NitTA, Y.-OKAMOTO, H.-HAMAKAWA, Y.: Amorphous Si: Heteroface Photovoltaic Cells based upon p-i-n Junction Structure, Jpn. J. Appl. Phys. 19 (1980), 143-148.
[7] OKAMOTO, H.-YAMAGUCHI, T.-NITTA, Y.-HAMAKAWA, Y.: Effect of DC Electric Field on the Basic Properties of RF Plasma Deposited a-Si. jour J. Non-Cryst. Solids.

[8] OKAMOTO, H.-NITTA, Y.-YAMAGUCHI, T.-HAMAKAWA, Y.: Device Physics and Design of a-Si ITO/p-i-n Heteroface Solar Cells, Sol. Cell Mater 2 (1980), 313-325.

[9] GRAY, W.-LOBODA, M.-BREMMER, J.-STRUYF, H.LEPAGE, M.-Van HOVE, M.-DONATON, R.-SLEECKX, E.-STUCCHI, M.-LANCKMANS, F.-GAO, T.-BOULLART, W.-COENGRACHTS, B.-MAENHOUDT, M.VANHAELEMEERSCH, S.-MEYNEN, H.-MAEX, K. : J. Electrochem. Soc. 150 (2003), G404.

[10] CHIANG, C.-CHEN, M.-KO, C.-WU, Z.-JANG, S.-LIANG, M.: Jpn. J. Appl. Phys. 42 Part 1 (2003), 4273.

[11] BAKLANOV, M.-Van HOVE, M.-MANNAERT, G.-VANHAELMEERSCH, S.-BENDER, H.-CONARD, T.-MAEX, K. : J. Vac. Sci. Technol. B 18 (2000), 1281.

[12] MATSUDA, Y.-RATHORE, J.-INTERRANTE, L.-DAUSKARDT, R.-DUBOIS, G.: ACS Appl. Mater. Interfaces 4 (2012), 2659.

[13] CHARLES-ALFRED, C.-Jousseaume, V.: Surf. Coat. Technol. 201 (2007), 9260.

[14] LANCKMANS, F.-GRAY, W.-BRIJS, B.-MAEX, K. : Microelectron. Eng. 55 (2001), 329.

[15] SHIMIZU, H.-TAJIMA, N.-KADA, T.-NAGANO, S.-OHASHI, Y.-HASAKA, S.: Jpn. J. Appl. Phys. 49 Part 1 (2010), 05FF02.

[16] FURUYA, A.-YONEDA, K.-SODA, E.-YOSHIE, T.-OKAMURA, H.-SHIMADA, M.-OHTSUKA, N.-OGAWA, S. : J. Vac. Sci. Technol. B 23 (2005), 2522.

[17] LOURO, P.et al : Use of a-SiC:H Photodiodes in Optical Communications Applications, Advances in Photodiodes (2011).

[18] MAGAFAS, L. : Study of Optical Sensors of the Form Al/a-SiC: $\mathrm{H} / \mathrm{c}-\mathrm{Si}$ (n) with High Sensitivity, Journal of Engineering Science and Technology Review (2008).

[19] KUMBHAR, A. et al : Photoluminescent, Wide-Bandgap a-SiC: H Alloy Films Deposited byCat-CVD using Acetylene, Thin Solid Films 395(1-2) (2001), 244-248.

[20] CARREnO, M. N. P. et al : Self-Sustained Bridges of a-SiC:H Films Obtained by PECVD Atlow Temperatures for MEMS Applications, Journal of Non-Crystalline Solids (2004), 338-340, 490-495.

[21] PERNÝ, M. et al : Optimalization of Amorphous Silicon Carbide Thin Films for Heterojunction Solar Cells, In: 28th European Photovoltaic Solar Energy Conference and Exhibition: Proceedings, Paris, France, 30 September - 4 Ocober 2013 München: WIP, 2013, pp. 1915-1918.

[22] FAHRNER, W. R.: Amorphous Silicon / Crystalline Silicon Heterojunction Solar Cells, Springer, 2013.

[23] FAHRNER, W. R.-MUELLER, T.-SCHERFF, M.-KNOENER, D.-NEITZERT, H. C. : Interface States Heterojunction Solar Cells, In: Proceedings of 4th World Conference Photovoltaic Energy Conversion, 2006, pp. 1822-182.

[24] PINGREE, L. S. C.-SCOTT, B. J.-RUSSELL, M. T.MARKS, T. J.-HERSAM, M. C. : Negative Capacitance in Organic Light-Emitting Diodes, Applied Physics Letters 86 (2005), 073509.

[25] PINGREe, L. S. C.-SCOTT, B. J.-RUSSELL, M. T.MARKS, T. J.-HERSAM, M. C.: Applied Physics Letters 86 (2005), 073509.

[26] PERERA, A. G. U.-SHEN, W. Z.-ERShOV, M.-LIU, H. C.-BUCHANAN, M.-SCHAFF, W. J. : Applied Physics Letters $\mathbf{7 4}$ (1999), 3167. 
Milan Perný was born in Slovakia in 1985. He graduated the Faculty of Electrical Engineering and Information Technology, Slovak University of Technology in Bratislava (SUT FEI) in 2009 as Diploma Engineer in Materials and technology. He is working in material science, photovoltaics and renewable energy sources research. At present he works at the Institute of Power and Applied Electrical Engineering, Slovak Technical University in Bratislava. Main interests of his research include DC and AC diagnostics methods in the field of homojunction and heterojunction solar cells.

Miroslav Mikolášek was born in Myjava (Slovakia), in 1983. He carried out research in the area of microfluidic circuits at the Johannes Kepler University in Linz, Austria, and based on this work he received his Master degree in electronics from the Slovak University of Technology, Bratislava, in 2007. In year 2011 he received PhD degree in Electronics from the Slovak University of Technology. At present he works at the Institute of Electronics and Photonics, Slovak Technical University in Bratislava. Main interests of his research include simulation and diagnostics in the field of solar cells based on amorphous silicon.

Michal Váry, born in Nitra, Slovakia in 1979. He graduated from the Slovak University of Technology in Bratislava, Faculty of Electrical Engineering and Information Technologies in 2004. He received the $\mathrm{PhD}$ degree in electrical engineering, materials and technologies, from the Slovak University of Technology in Bratislava, in 2009 and at present is the assistant professor at Institute of Power and Applied Electrical Engineering, Department of Materials and Technologies, of his Alma Mater. His research interests include: cable insulation systems aging, polarization processes in dielectric mate- rials, monitoring of photovoltaic systems performance, aging of photovoltaic systems encapsulation materials.

Vladimír Šály was born in Slovakia in 1956. Faculty of Electrical Engineering and Information Technology, Slovak University of Technology in Bratislava (SUT FEI) finished as Diploma Engineer (MSc.) in Electrotechnology and in 1985 he received the scientific degree $\mathrm{PhD}$. from the same university. Since 2003 he is employed as Associated Professor at SUT FEI. He works in material science, interesting especialy in dielectric and semiconductor structures and photovoltaic renewableenergy sources research.

Juraj Packa was born in Slovakia in 1971. Faculty of Electrical Engineering and Information Technology, Slovak University of Technology in Bratislava (SUT FEI) finished as Diploma Engineer (MSc.). He received the scientific degree $\mathrm{PhD}$ in Electrotechnology and Materials from the same university in 2004. Since 2001 he is employed as Assistant Professor at SUT FEI. He works in material science, photovoltaics and electrical insulation systems.

Jozef Huran was born in 1955 in Slovakia. He graduated the Faculty of Electrical Engineering of the Electrical Engineering and Information Technology, Slovak University of Technology in Bratislava in Bratislava (1980). Thesis titled "Impact of technology steps on the characteristics of the experimental Si detectors of ionizing radiation" was defended in 1990. He work at Slovak Academy of Sciences in Bratislava at present as a researcher in the field of forming technology and production of advanced semiconductor devices based on $\mathrm{SiC}$, AlN for applications in microelectronics and optoelectronics.

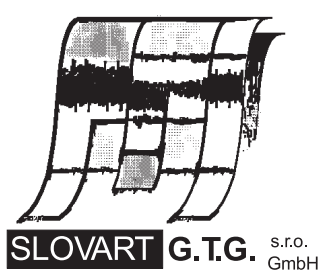

EXPORT - I MPORT
E X P OR T - I M P OR T

of periodicals and of non-periodically printed matters, books and CD-ROMs

Krupinská 4 PO BOX 152, 85299 Bratislava 5, Slovakia tel: ++421 263839 472-3, fax: ++421263839485 info@slovart-gtg.sk; http://www.slovart-gtg.sk

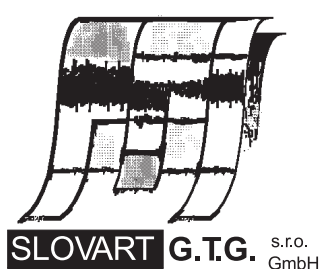

EXPORT - IMPORT 